\title{
RESPONDING TO ACCOUNTABILITY PREDICAMENTS: IMPRESSION MANAGEMENT IN VOLUNTARY CORPORATE ANNUAL REPORT DISCLOSURES
}

\author{
Merridee L. Bujaki \\ Sprott School of Business, Carleton University, Ottawa, Ontario, Canada \\ and Bruce J. McConomy \\ Lazaridis School of Business \& Economics, Wilfrid Laurier University, \\ Waterloo, Ontario, Canada
}

\begin{abstract}
Tntegrative research into Corporate Annual Report (CAR) disclosures is undertaken by simultaneously examining financial performance, Letters to Shareholders (LTS) and photographs of a large Canadian grocery retailer (Loblaw Companies Limited). The Company's use of impression management is assessed by examining disclosures across three years, two leaders and in periods of profit and loss. We find evidence of impression management in LTS, photographs of executive leaders, CAR cover photographs, and the framing of financial performance. Overall, voluntary disclosures provide incremental information that supports and supplements mandatory disclosures. We conclude that impression management in voluntary disclosures helps to legitimate the change in leadership at Loblaw.
\end{abstract}

\section{INTRODUCTION}

This paper evaluates voluntary Corporate Annual Report (CAR) disclosures for Canada's largest grocery retailer, Loblaw Companies Limited (Loblaw), building on the notion that text, photos and financial results all form part of the corporate 'language' used in CARs (David, 2001; Davison, 2014). This paper contributes to 
the voluntary disclosure, impression management and organisational legitimacy literatures by examining how voluntary corporate disclosures are managed to legitimate change in leadership. Clatworthy and Jones (2003) argue that voluntary accounting narratives, such as Letters to Shareholders (LTS), are unaudited and subject to impression management. Aerts (2005) observes that incentives for impression management are strongest when organisations are responding to an 'accountability predicament' that threatens the organisation's legitimacy. Such accountability predicaments arise when performance is poor (Aerts, 2005; Clatworthy and Jones, 2006), in the case of changes in CEO (Godfrey, Mather and Ramsay, 2003), and during times of crisis or controversy (Beelitz and Merkl-Davies, 2012). Related research suggests that impression management can be applied to financial information (Clatworthy and Jones, 2006; Garcia Osma and Guillamon-Saorin, 2011; Godfrey et al., 2003), text (Aerts, 2005; Beelitz and Merkl-Davies, 2012; Clatworthy and Jones, 2006; Ogden and Clarke, 2005) and photographs in CARs (Beattie, Dhanani and Jones, 2008; Graves, Flesher and Jordan, 1996; McKinstry, 1996). Several authors have noted the importance of examining impression management in sequential annual reports (Beattie et al., 2008; Beelitz and Merkl-Davies, 2012; Clatworthy and Jones, 2003; Godfrey et al., 2003).

Loblaw faced an accountability crisis in 2006: it reported its first net loss in nineteen years, its long-serving chairman and president both resigned, and an inexperienced executive chairman (the son of the previous chairman) was appointed to lead the company. Initial reaction to these events in both the financial analyst community and the stock market was surprise. For example, changes in Loblaw's leadership were described as a 'shakeup' and there was a sense that the next generation of the family needed 'to prove its mettle' (Olijnyk, 2006), and one analyst commented, 'I never thought he would have been a significant management factor at the company within any reasonable time frame' (National Post, 2006). Loblaw's share price dropped slightly immediately following Galen G. Weston's appointment as executive chairman in 2006 from $\$ 42.37$ per share to $\$ 41.53$ per share (Yahoo Finance, 2014). Loblaw's use of impression management in narrative and visual voluntary disclosures in its 2005, 2006 and 2007 CARs is examined as Loblaw addressed the accountability predicaments that threatened its legitimacy. Overall we assess the extent of impression management within Loblaw's LTS, evidence of impression management in the photographs of executive leaders in Loblaw's CARs, and the extent to which Loblaw's impression management activities may be understood as efforts to restore organisational legitimacy. The remainder of the paper is organised as follows. The next section reviews the relevant literature. Loblaw's background is then discussed and research questions are formulated. The methodology is then presented, followed by results and conclusions.

\section{LITERATURE REVIEW}

Threats to organisational legitimacy often lead to efforts to manage the impressions stakeholders have of a company. Impression management in CARs can be applied to financial results as well as voluntary disclosures. Voluntary disclosures 
in CARs include narratives and visuals. The specific narrative components of CARs focused on in this paper are LTS and the overall motto for the CAR, while the visual disclosures addressed are photographs. This literature review summarises links between threats to legitimacy and impression management in CARs, earnings and impression management, and impression management in voluntary disclosures, specifically impression management in LTS and photographs.

\section{Impression Management}

According to Clatworthy and Jones (2003, p. 173), 'The theory and practice of impression management is well documented in accounting research ... In theory, company management have incentives to represent their company's performance in the best possible light.' In CARs, impression management techniques can be applied to either financial statements or voluntary disclosures. Impression management involves the creation of a public impression, usually with the purpose of making the organisation more appealing to stakeholders. The impression conveyed may match a perceived reality, or it may entail enhancing desirable aspects of the organisation or obfuscating less desirable aspects, thus attempting to manage stakeholders' impressions. ${ }^{1}$ Impression management is intended to influence stakeholder perceptions of financial and social performance, organisational legitimacy and organisational changes. Impression management in CARs can be used to influence the interpretation of management's decisions and choices or to obscure political processes that underlie many corporate decisions (Merkl-Davies and Brennan, 2011). To the extent that impression management reduces the quality of corporate disclosures, organisations and their activities may receive unwarranted support from their stakeholders. Thus it is important that CAR readers be aware of the potential for impression management.

\section{Impression Management in CARs as a Response to Legitimacy Threats}

Impression management can be used by organisations to gain, maintain or repair organisational legitimacy (Suchman, 1995) or as a reaction to an 'accountability predicament' (Aerts, 2005). Impression management can be used at any time, but the use of corporate communications to restore organisational legitimacy through managing perceptions during times of crisis or controversy is particularly common (Arndt and Bigelow, 2000; Beelitz and Merkl-Davies, 2012; Merkl-Davies and Brennan, 2011). Merkl-Davies and Brennan indicate that 'impression management entails presenting an image of the organisation as a rational entity, often by means of rationalising decisions in order to gain or maintain social legitimacy' (2011, p. 424). Further, 'managers may be prompted to engage in impression management to counteract undesirable consequences of information releases in the form of unfavourable analyst reports and credit ratings, negative share price movements and loss of stakeholder support' (2011, p. 425). According to Beelitz and Merkl-Davies (2012, pp. 101-102), 'In times of crisis or controversy, such as during financial scandals, environmental disasters and major structural re-organisation, management uses corporate communication to restore organisational legitimacy by persuading audiences that the organisation is re-aligning its structures and procedures with social norms and rules.' 


\section{Earnings and Impression Management}

Clatworthy and Jones (2006) argue that incentives for using impression management are greatest among companies with declining financial performance. Aerts (2005, p. 495) observes that the impression management techniques used in response to a downturn in financial performance are 'self-presentational attributions' that frame negative outcomes as the result of 'external events or chance factors (business climate, inflation, market prices, government policy, weather)'. Prior research has also found income-reducing behaviour in the year of a change in CEO, followed by income-increasing behaviour in the year immediately after (Godfrey et al., 2003; Pourciau, 1993). When there is a change in CEO, the new CEO needs to manage the expectations of the board and earn the confidence of stakeholders. There is an opportunity in the corporate disclosures to attribute the company's poor performance to the prior CEO (Clatworthy and Jones, 2006) in a form of 'ritual scapegoating' (Abrahamson and Park, 1994, p. 1310). Alternatively, 'the new CEO may deal with problems previously ignored by the old management. In other words, the new CEO is recording write-offs that should have been made by the previous management' (Godfrey et al., 2003, p. 99).

A newly appointed CEO has incentives to engage in impression management to maximise his or her human capital and tenure. Managing shareholder expectations and earning the confidence of corporate stakeholders by achieving a set of realistic performance goals in their first year or two assists in this regard (ibid.). 'Anecdotal and empirical evidence suggests a downward earnings management in the year of a chief executive officer (CEO) change and upward management in the following year. The context-specific evidence from the U.S. is generally consistent with incoming CEO's "taking a bath"' (ibid., p. 95), since a big bath establishes a low benchmark against which subsequent performance is judged. Impression management by new CEOs, however, is context-dependent. Godfrey et al. (2003) find that impression management by a new CEO is less likely if the old CEO remains in a position from which he or she can monitor the incoming CEO's performance (for example, by remaining on the Board of Directors). Regardless of how a new CEO is appointed, the corporation needs to address concerns over the legitimacy and rationality of the choice of CEO to assure stakeholders of the incoming CEO's competence (Aerts, 2005) and to maintain or regain the organisation's social legitimacy (Godfrey et al., 2003).

\section{Impression Management in Letters to Shareholders}

LTS fall within the voluntary disclosure domain. LTS help frame shareholder expectations for the future and explain past results. LTS can manage impressions, inspire changes in attitudes, increase commitment and influence behaviour (Amernic, Craig and Tourish, 2007). LTS are important elements of corporate disclosure as they are widely read (Devinney and Kabanoff, 1999; Hyland, 1998), are a rich source of symbolic meaning (Prasad and Mir, 2002) and provide explanations (Abrahamson and Amir, 1996) and attributions (Bettman and Weitz, 1983) beyond those in financial statements. LTS convey beliefs and values (David, 2001; Helms Mills, 2005), indicate CEOs' mindset and leadership (Amernic et al., 2007) and influence stakeholders (Maltby and Tsamenyi, 2010). Bettman and Weitz (1983) found a pattern of selfserving attributions in LTS such that favourable outcomes tend to be attributed to 
managerial action (see also Clarke, 1997; Clatworthy and Jones, 2006), while unfavourable outcomes tend to be attributed to 'external, unstable, and uncontrollable causes' (ibid., p. 181). Similarly, Thomas (1997, p. 47) observed that 'as the news becomes more negative, linguistic structures suggest a factual, "objective" situation caused by circumstances not attributable to any persons who might otherwise be thought responsible'.

There is considerable evidence that corporations generally try to present a positive picture of their performance (Aerts, 2005; Beattie et al., 2008; Clatworthy and Jones, 2006), particularly in their LTS. In their study of highly profitable versus highly unprofitable UK companies, Clatworthy and Jones (2006) find poorly performing corporations discuss future plans and prospects in their LTS to avoid addressing poor present performance. Kohut and Segars (1992) found high-return-on-equity firms are more verbose than low-return-on-equity firms, leading to longer LTS, though Clatworthy and Jones (2006) found no significant difference in the length of LTS for profitable versus unprofitable companies. Aerts (2005) argues that negative outcomes need to be explained to be legitimated, but positive outcomes signal competence and therefore do not need to be explained, possibly leading to shorter LTS.

\section{Impression Management in CAR Photographs}

Clatworthy and Jones (2006) observe that recent impression management research has focused on photographs (Graves et al., 1996; McKinstry, 1996). Although they did not examine photographs themselves in their exploration of legitimation strategies of privatised water companies in the UK, Ogden and Clarke (2005, p. 341) noted that 'Photographs ... have become increasingly common in recent reports and they well may merit separate recognition in the analysis of how corporate reports are used to manage legitimacy'. According to Beattie et al. (2008, p. 188), 'Overall, prior research into pictures in annual reports has highlighted their importance as a technique of impression management in making the reports visually more attractive and conveying particular types of messages'. Photographs in CARs tell a story and elicit emotions (Davison, 2007) to manage readers' impressions of the company. More recently, Davison (2014, p. 21) makes the case that visual images in annual reports are important, in part, because 'pictures have interwoven roles as incremental information and impression management'. Thus it is important to explore the impressions that photographs in CARs convey through their visual rhetoric (Scott, 1994), which requires time and conscious thought to decode (Davison, 2007, 2014; McGoun, Bettner and Coyne, 2007). Helms Mills (2005) found that CAR photographs provide information about corporate priorities and values, and Davison and Warren (2009) provide a discussion of some key issues relating to visual perspectives on accounting, accountability and visual impression management.

\section{BACKGROUND}

\section{Canadian Retail Grocery Sector and Loblaw Companies Limited}

George Weston founded a bakery in Toronto in 1896, which eventually became Weston Food Ltd. George's son, W. Garfield Weston, took over the company when 
George died in 1924 but the company struggled during the Depression. In 1932, Garfield moved his family back to the United Kingdom and built a large food processing and retailing company there, returning to Canada in 1945.

Loblaw Groceterias was founded in 1919 in Toronto, Ontario, and offered an innovative approach to grocery shopping - as a self-serve, cash and carry store. In 1947, W. Garfield Weston acquired an ownership interest in the company, increasing this to a controlling interest by the early 1950s. In 1956, Loblaw Companies Limited (Loblaw) was incorporated and acquired all the shares of Loblaw Groceterias. In 1961, Garfield's son, W. Galen, moved to Dublin, Ireland, to begin his own grocery business. While in Ireland, Galen married Hilary Frayne and purchased the Brown Thomas department-store chain. In the early 1980s, the family was the target of an unsuccessful Irish Republican Army kidnapping attempt (New York Times, 1983). This, and an opportunity to revitalise the struggling Loblaw grocery-store chain owned by his father, led to Galen's return to Canada.

Loblaw, Canada's largest grocery retailer and one of the country's largest private sector employers, had 609 corporate stores across Canada in 2008 operating under 21 different banners (Loblaw, 2008). In 2005, the Canadian food retail industry generated revenues of US\$62 billion, US\$29.5 billion (47.6 per cent) of which was from the supermarket segment. Within this segment, Loblaw was the dominant player, generating US\$19.6 billion in sales (Datamonitor, 2006). Thus, Loblaw generated approximately 66 per cent of all revenue in the Canadian retail grocery sector, more than double the size of its nearest competitor. Loblaw is known particularly for its control-label or private-label products. In recent years, Loblaw expanded beyond its traditional grocery roots and now sells household, clothing and seasonal products as well. W. Galen Weston served as CEO, and later chairman, of Loblaw Companies Limited from 1972 (at age 31) until 2006. He appointed his son, Galen G. Weston, executive chairman of Loblaw on 19 September 2006. Galen Weston (Senior) continues as executive chairman of George Weston Ltd, which is the majority shareholder for both Loblaw Companies Limited and Weston Food Ltd. Today, the Weston family ranks as Canada's second-wealthiest family, Hilary Weston was considered Ireland's richest person for many years (Poisson, 2012) and the family is listed among the fifteen richest families in the United Kingdom due to their international interests in food and fashion retailing.

The appointment of Galen G. Weston (Junior) as executive chairman of Loblaw in 2006 represented a threat to the company's legitimacy on a number of fronts. Galen G. Weston Jr was appointed executive chairman at the age of 33, at 'one of the most troubled times in company history' (Olijnyk, 2006), when the company's stock was struggling (CBC, 2013). ${ }^{2}$ At the time, Galen G. Weston Jr was appointed executive chairman (equivalent to chairman and CEO), Loblaw was 'having problems in its core food business, is heading into union negotiations and is facing the opening of Wal-mart Supercenters in Ontario' (Canadian Business, 2006). Although Galen Weston Jr had been working at Loblaw since 1998, his role as executive chairman encompassed chairman of the board, as well as responsibilities for 'retail operations, labour relations, the President's Choice banking unit, real estate and store construction' (ibid.). One anonymous analyst commented at the time: 'So now we've got one of these beautiful Canadian family nepotism things' (ibid.). At the time of 
Galen Weston Jr's appointment, the resignation of Loblaw's long-serving president, John Lederer, was also announced and analysts saw Lederer's resignation as a loss for the company at a difficult time. Thus the legitimacy of Loblaw's leadership was questioned by financial analysts and the Canadian business press on a number of fronts: the relative youth and inexperience of Galen G. Weston Jr, the change in leadership at a challenging time during the company's history, the wide range of responsibilities assigned to Galen G. Weston Jr, the loss of experienced operational and strategic leadership, and allegations of nepotism (Canadian Business, 2006; National Post, 2006).

\section{RESEARCH QUESTIONS}

1. Do Loblaw's LTS provide evidence of impression management, particularly a pattern of self-presentational attributions?

2. Is there evidence of impression management in the photographs in Loblaw's CARs, particularly in the photographic portraits of executive leadership?

3. Can Loblaw's impression management activities be understood as efforts to restore organisational legitimacy?

\section{RESEARCH METHOD}

Many studies have focused on impression management in companies' LTS (e.g. Abrahamson and Amir, 1996; Bettman and Weitz, 1983; Hyland, 1998; Prasad and Mir, 2002) or photographs in CARs (e.g. Benschop and Meihuizen, 2002; Davison, 2007, 2010; Helms Mills, 2005; Singh and Point, 2006). However, it is difficult to examine impression management in corporate disclosures as it cannot be observed directly (Garcia Osma and Guillamon-Saorin, 2011), but must be inferred from an examination of disclosure practices and trends.

According to Beelitz and Merkl-Davies (2012, p. 102), corporate communications can be understood as a 'discursive negotiation of legitimacy between management and organisational audiences over time'. Thus to understand responses to threats to organisational legitimacy, it is important to evaluate disclosures over time. The importance of a multi-year analysis is reinforced by Beattie et al.'s observation (2008, p. 186) that most impression management 'studies are, in the main, cross-sectional and provide little meaningful, comparable information on trends over time'.

For this study, Loblaw CARs for each fiscal year ending 2004 to 2008 were obtained from the System for Electronic Document Analysis and Retrieval website. ${ }^{3}$ Financial results for each year were obtained from audited financial statements in the appropriate CAR. Total assets, fixed assets, total liabilities, shareholders' equity, sales, net income and cash from operations were extracted from each year's financial statements (see Table 1 and related discussion below). The following ratios were calculated: return-on-assets, return-on-equity, debt-to-equity, fixed assets as a percentage of total assets and profit margin. Other performance indicators were noted 
from the CARs, including earnings per share, dividends per share, closing share price and the number of corporate stores.

LTS have been examined using both quantitative and qualitative methods in prior research. Devinney and Kabanoff (1999) relate quantitative measures of words to other quantitative data about the firm (level of assets, return-on-assets). Hyland (1998) analysed LTS qualitatively through close textual and linguistic analysis. In addition, qualitative identification of key words (Suddaby and Greenwood, 2005) and metaphors (Amernic et al., 2007; Bujaki and McConomy, 2012) in LTS have been combined with frequency counts. We build on prior research using phrases or sentences as the level of analysis, since a sentence contains sufficient information to convey meaning (Bettman and Weitz, 1983; Prasad and Mir, 2002). The number of sentences per LTS was counted, and the themes contained in individual sentences were determined by a trained research assistant (we use the term 'theme' in the sense of prominent/frequently recurring topics discussed in the sentences that make up the LTS). ${ }^{4}$ In addition, the authors counted the number of references in each LTS to the past and the future, and the extent to which negative outcomes are attributed to external events/chance factors (vs internal/controllable factors). ${ }^{5}$

Within the CAR, we focus on voluntary disclosures linked to executive leadership as 'the CEO is the organisational actor primarily in charge of legitimacy construction' (Beelitz and Merkl-Davies, 2012, p. 109). Thus we focus on LTS, mottos for each CAR and photographic portraits of the executive leaders in the year of transition (2006) and the year immediately before and after the transition year (2005-2007). In particular, to assess research question 1 , we consider the extent to which leadership, values and attributions are communicated in Loblaw's voluntary CAR disclosures in a manner consistent with impression management.

The number and content of each year's CAR photographs were assessed. Photographic content was coded to indicate the subject of each photograph: e.g. employee, customer, product, facility. Regarding research question 2, we focus on the visual rhetoric of the portraits of Loblaw's executive leaders that accompanied each LTS. Visual rhetoric addresses how visual images communicate meaning, including both denotative (representational) meaning and connotative (symbolic) meanings (Barthes, 1982; Davison, 2014). Davison (2010) examined four aspects of visual rhetoric in CAR portraits of CEOs, exploring how physical attributes, attire, spatial context and interpersonal relationships communicate characteristics (tangible and intangible) of the individual leaders pictured. We followed the same approach in conducting rhetorical analysis of photographs of Loblaw's executive leaders. In particular, following prior research, we analysed the values and leadership styles connoted by photographs of Loblaw's executive leaders (David, 2001; Davison, 2010; Scott, 1994).

Overall, the methodology described above is designed to assess Loblaw's impression management activities and the extent to which they help to legitimate the transition from father to son as executive leader (research question 3). 


\section{RESULTS}

In this section, we first provide a review of Loblaw's financial results for the 20042008 period, followed by an overview of the content of the Company's annual reports for the transition period. We then provide a summary of the CAR photographs for the transition period. Finally, we look in more detail at Loblaw's results and voluntary disclosures for each year of the transition period (2005-2007). A separate discussion section follows the results.

\section{Overview}

\section{Corporate Financial Performance}

Table 1 summarises key aspects of Loblaw's financial performance in fiscal years 2004 to 2008 (all amounts in Canadian dollars). We include the two years before and after the transition year to provide context. However, as noted in the method section, we focus on the transition year and the year before and after transition in subsequent analyses. As Table 1 indicates, sales grew steadily year over year from 2005 to 2007. Increasing sales, in spite of a decline in the number of stores in 2007, accentuated the growth in sales on a per-store basis. All measures of profitability reported in Table 1 reflect a similar pattern of results: deterioration of net income, profit margin, return-on-assets, return-on-equity and earnings per share in 2006 relative to 2004 and 2005, and then gradual improvements in 2007 and 2008. In particular, 2006 was marked by a net loss of $\$ 219$ million, due primarily to an $\$ 800$ million write-off of goodwill. Without the write-off, Loblaw's 2006 net income would have been $\$ 581$ million, and the trend in net income would have continued to decline into 2007. Loblaw's total assets declined slightly in 2006 (vs 2005) and then grew gradually in 2007 and 2008. Loblaw's liabilities grew each year. Dividends increased to $\$ 0.84$ per share in 2005 and remained unchanged during the following years. Loblaw's year-end share price dropped steadily from $\$ 72.02$ in 2004 to \$34.07 in 2007, before edging up in $2008 .{ }^{6}$ Taken together, Loblaw's financial results indicate the company faced a financial accountability predicament in 2006 with earnings and share price under significant pressure, relative to the years surrounding the transition year.

\section{Letters to Shareholders (LTS)}

We first provide a brief overview of the content of the LTS over the 2005-2007 period, followed by a more detailed year-by-year analysis. We summarise the key themes in each of the annual reports, by year in Table 2 (we highlight six key themes per year in the table, as these make up over 50 per cent of the themes addressed on a year-by-year basis). ${ }^{7}$ The 2005 LTS, written by W. Galen Weston (Senior) focused on organisational and operational issues, including implementation of changes and a focus on organisational structure and operational improvements, as well as financing to pay for these changes. Implementation of changes and growth were important and recurring themes over the three-year period and were included in the top-six list each year. In addition to the recurring themes, the 2006 transitional year LTS focused on products, strengths, implementation of changes, growth, operational improvement and strategic themes. The LTS comments directly on 2006's 
Bujaki and McConomy

TABLE I: FINANCIAL RESULTS (MILLIONS REFER TO CANADIAN DOLLARS, UNLESS OTHERWISE NOTED)

\begin{tabular}{|c|c|c|c|c|c|}
\hline 2004 & 2005 & Fiscal Year & 2006 & 2007 & 2008 \\
\hline $\begin{array}{l}\text { W.G. } \\
\text { Weston Sr }\end{array}$ & $\begin{array}{c}\text { W.G. } \\
\text { Weston Sr }\end{array}$ & $\begin{array}{l}\text { Description (amounts in } \\
\text { millions, unless per share) }\end{array}$ & Transition & $\begin{array}{c}\text { G.G. } \\
\text { Weston Jr }\end{array}$ & $\begin{array}{c}\text { G.G. } \\
\text { Weston Jr }\end{array}$ \\
\hline 26,209 & 27,627 & Sales & 28,640 & 29,384 & 30,802 \\
\hline 968 & 746 & Net income & -219 & 330 & 545 \\
\hline $3.69 \%$ & $2.70 \%$ & Profit margin & $-0.76 \%$ & $1.12 \%$ & $1.77 \%$ \\
\hline 13,046 & $|3,76|$ & Total assets & 13,486 & 13,674 & 13,985 \\
\hline $7.42 \%$ & $5.52 \%$ & Return-on-assets & $-1.62 \%$ & $2.41 \%$ & $3.90 \%$ \\
\hline 7,113 & 7,785 & Fixed Assets (FA) & 8,055 & 7,953 & 8,045 \\
\hline $54.52 \%$ & $56.57 \%$ & $\mathrm{FA}$ as a $\%$ of total assets & $59.73 \%$ & $58.16 \%$ & $57.53 \%$ \\
\hline 7,632 & 7,875 & Total liabilities & 8,045 & 8,129 & 8,155 \\
\hline 5,414 & 5,886 & Shareholders' equity & 5,441 & 5,545 & 5,830 \\
\hline $17.88 \%$ & $12.67 \%$ & Return-on-equity & $-4.02 \%$ & $5.95 \%$ & $9.35 \%$ \\
\hline 1.41 & 1.34 & Debt/equity & 1.48 & 1.47 & 1.40 \\
\hline ।,443 & ।,489 & Cash from operations & 1,180 & 1,245 & 989 \\
\hline$\$ 3.53$ & $\$ 2.72$ & Earnings per share $(\$)$ & $-\$ 0.80$ & $\$ 1.20$ & $\$ 1.99$ \\
\hline$\$ 0.76$ & $\$ 0.84$ & Dividend per share $(\$)$ & $\$ 0.84$ & $\$ 0.84$ & $\$ 0.84$ \\
\hline$\$ 72.02$ & $\$ 56.37$ & Share price $(\$)$ & $\$ 49.00$ & $\$ 34.07$ & $\$ 35.23$ \\
\hline 658 & 670 & Number of corporate stores & 672 & 628 & 609 \\
\hline 1,062 & 1,072 & Total number of stores & I,077 & 1,032 & 1,036 \\
\hline
\end{tabular}

poor financial performance (as discussed further below) and is much more focused on the future than the other LTS examined. In addition to the recurring themes, the 2007 LTS written by Galen G. Weston Jr addresses finance-related issues and challenges faced by Loblaw as the most prevalent theme for the year's LTS. In terms of the relative focus on explaining the past versus outlining the future of the Company, the 2007 LTS is the most balanced of the three LTS.

The 2005 LTS written by W. Galen Weston Sr is much longer than that written by his son in 2007 (91 sentences compared to 28 sentences). The 2006 LTS was 98 sentences long. In comparison, the 2008-2010 LTS gradually increased in length, but are still not as long as the LTS in 2005 and 2006. This may reflect, in part, the fact that Loblaw introduced a Corporate Social Responsibility report beginning in 2007. Because of the additional length of W. Galen Weston Sr's earlier LTS, he addresses more themes in his LTS than does his son. The mottos taken from the covers of the CARs for each of the years examined are: 2005: 'We are aligning for success'; 2006: 'Simplify, Innovate, Grow'; and 2007: 'Making Loblaw the Best Again'. The mottos are discussed further below.

\section{Annual Report Photographs}

The number of photos in Loblaw's CARs varied from 119 (in 2005) to 58 (in 2006), down to 1 (in 2007). The majority of photographs are colour and most are smaller 
Responding to Accountability Predicaments

TABLE 2: THEMES IN LETTERS TO SHAREHOLDERS

\begin{tabular}{|c|c|c|c|c|c|c|c|}
\hline \multicolumn{2}{|l|}{ Fiscal year } & \multicolumn{2}{|c|}{2005} & \multicolumn{2}{|c|}{2006} & \multicolumn{2}{|c|}{2007} \\
\hline \multicolumn{2}{|l|}{ Chairman } & \multicolumn{2}{|c|}{$\begin{array}{l}\text { W. Galen } \\
\text { Weston Sr }\end{array}$} & \multicolumn{2}{|c|}{ Transition } & \multicolumn{2}{|c|}{$\begin{array}{l}\text { Galen G. } \\
\text { Weston Jr }\end{array}$} \\
\hline \multicolumn{2}{|l|}{ Title of letter } & \multicolumn{2}{|c|}{$\begin{array}{l}\text { Report to } \\
\text { share- } \\
\text { holders }\end{array}$} & \multicolumn{2}{|c|}{$\begin{array}{l}\text { Report of } \\
\text { operations }\end{array}$} & \multicolumn{2}{|c|}{$\begin{array}{l}\text { Report to } \\
\text { share- } \\
\text { holders }\end{array}$} \\
\hline \multicolumn{2}{|l|}{ Signatures } & \multicolumn{2}{|c|}{$\begin{array}{l}\text { Chairman } \\
\text { President }\end{array}$} & \multicolumn{2}{|c|}{$\begin{array}{l}\text { Executive } \\
\text { Chairman }\end{array}$} & \multicolumn{2}{|c|}{$\begin{array}{l}\text { Executive } \\
\text { Chairman }\end{array}$} \\
\hline \multicolumn{2}{|l|}{ CAR theme } & \multicolumn{2}{|c|}{$\begin{array}{l}\text { We are ... } \\
\text { aligning for } \\
\text { success }\end{array}$} & \multicolumn{2}{|c|}{$\begin{array}{l}\text { Simplify, } \\
\text { Innovate, } \\
\text { Grow }\end{array}$} & \multicolumn{2}{|c|}{$\begin{array}{l}\text { Making } \\
\text { Loblaw the } \\
\text { best again }\end{array}$} \\
\hline \multirow{2}{*}{\multicolumn{2}{|c|}{ Number of sentences in LTS }} & \multicolumn{2}{|l|}{91} & \multicolumn{2}{|l|}{97} & \multicolumn{2}{|l|}{28} \\
\hline & & \# & $\%$ & \# & $\%$ & \# & $\%$ \\
\hline References to past & & 84 & 70 & 39 & 41 & 20 & 50 \\
\hline References to future & & 36 & 30 & 56 & 59 & 20 & 50 \\
\hline Total number of themes addressed' & & 204 & 100 & 216 & 100 & 51 & 100 \\
\hline Themes (top 6 for year) & 2005 & \# & $\%$ & & & & \\
\hline Implementation of changes & I & 29 & 14.2 & & & & \\
\hline Organisational structure & 2 & 21 & 10.3 & & & & \\
\hline Operational improvement & 3 & 16 & 7.8 & & & & \\
\hline Finance & T4 & 15 & 7.4 & & & & \\
\hline Growth & T4 & 15 & 7.4 & & & & \\
\hline Employees & 6 & 14 & 6.9 & & & & \\
\hline Total & & 110 & 53.9 & & & & \\
\hline Themes (top 6 for year) & 2006 & & & $\#$ & $\%$ & & \\
\hline Products & 1 & & & 24 & 11.1 & & \\
\hline Strengths & 2 & & & 20 & 9.3 & & \\
\hline Implementation of changes & 3 & & & 18 & 8.3 & & \\
\hline Growth & T4 & & & 17 & 7.9 & & \\
\hline Operational improvement & $\mathrm{T} 4$ & & & 17 & 7.9 & & \\
\hline Strategy & 6 & & & 16 & 7.4 & & \\
\hline Total & & & & 112 & 51.9 & & \\
\hline
\end{tabular}


TABLE 2 (CONTINUED)

\begin{tabular}{llccc}
\hline \multicolumn{1}{c}{ Fiscal year } & & 2005 & 2006 & \multicolumn{2}{c}{2007} \\
\hline Themes (top 6 for year) & 2007 & & $\#$ & $\%$ \\
Finance & $\mathrm{I}$ & & 9 & 17.6 \\
Implementation of changes & $\mathrm{T} 2$ & 6 & 11.8 \\
Organisational structure & $\mathrm{T} 2$ & & 6 & 11.8 \\
Growth & $\mathrm{T} 4$ & 5 & 9.8 \\
Marketing & $\mathrm{T} 4$ & 5 & 9.8 \\
Weaknesses & $\mathrm{T} 4$ & 5 & 9.8 \\
Total & & 36 & 70.6 \\
\hline
\end{tabular}

\# = The number of sentences that contain the theme in the CAR.

$\%=$ Percentage inclusion rate of the theme for the year(s) (calculated as:

\#/Total number of themes addressed in the year).

' The 'Total number of themes addressed' row represents the total number of themes addressed in each year's CAR.

than one-quarter of a page. CAR photographs frequently depict Loblaw's facilities and control-label products (each averages approximately 30 per cent of the photos in 2005 and 2006). Fresh produce is also depicted regularly (about 10 per cent of photos each year). Of pictures including people, the majority of subjects are adult employees; few visible minorities are shown. Loblaw's 2005 CAR has the largest number of photos - most of which are thumbnail-sized and many of which are repeated elsewhere in the CAR. Almost half the 2006 photos are of control-label products. The 2007 CAR has only one photograph (a black-and-white picture on the CAR cover). We focus our analysis (below) on the portrait-style photographs of Loblaw's executive leaders that accompany the LTS.

\section{CAR}

\section{Financial Performance}

Loblaw's 2005 financial results reflect a growing company: sales, total assets, fixed assets, liabilities, cash from operations and number of stores all increased from the prior year (see Table 1). However, Loblaw's performance had declined, as illustrated by reduced profit margin, return-on-assets and return-on-equity ratios, relative to 2004. This pattern suggests that Loblaw was continuing to grow, yet was experiencing difficulty converting growth in sales and assets into profits, indicating greater operating costs and inefficiencies.

\section{Letter to Shareholders in 2005 Annual Report}

In Loblaw's 2005 LTS, implementation of changes and organisational restructuring were the focus of attention. This is consistent with the CAR motto: 'We are ... aligning for success'. The 2005 LTS repeatedly refers to Loblaw's organisational structure undergoing a transformation: 'In 2005, Loblaw Companies Limited moved closer to completing one of the largest transformations in its history. We were challenged by the size and impact of the short term costs associated with executing certain elements of the transformation' (Loblaw, 2005 CAR, p. 5). Several clues indicate this 
transformation will continue after 2005, for example, the wording 'moved closer', 'we are aligning', and, in the comment below, 'we made ... progress':

Loblaw implemented a number of transformative changes to its structure and operations. These changes were designed to align the different yet connected parts of our business into a more unified, efficient, cost-effective and nationally-focused organization. We made significant progress in pursuit of these goals in 2005. A number of office facilities were consolidated. A number of functions were reorganized. A national general merchandise organizational structure was established and a new head office and Store Support Centre ... was completed (Loblaw, 2005 CAR, p. 5).

However, the transformation was not an easy one:

We have acknowledged on previous occasions that the Company may have taken on too much, too quickly during the past year. This was especially evident in the delays surrounding the execution of planned changes to our national systems platform and supply chain. These delays disrupted the flow of inventory to our stores, which affected sales and earnings. We concluded, however, that the long term interests of the business, our shareholders and other stakeholders would be best served by our completing these measures as quickly as practicable (Loblaw, 2005 CAR, p. 5).

The impact of the changes to structure and operations was also discussed in terms of required capital expenditures and the negative impact on financial results (finance theme). Growth was discussed mainly in the context of the transformation leading to 'growth going forward'. Employees were seen as a key resource, but in need of training to strengthen and improve leadership at the store level (see Table 2).

Internal and external attributions for performance were used in the 2005 LTS. W. Galen Weston Sr accepted some responsibility for Loblaw's challenges in having 'taken on too much', identified key challenges as centred in the distribution and supply chain, and linked this explicitly with an impact on financial results. In particular, he explained the need for significant transformation as resulting from 'the fast-changing retail landscape and of our place in it. That landscape is increasingly marked by such factors as an over-supply of retail square-footage, the consumer's desire for a value-driven shopping experience, and the presence of low-cost global retailers' (Loblaw, 2005 CAR, p. 5). In addition, the 2005 LTS is marked by more than twice as many references to past activities and accomplishments (e.g. 'developed', 'implemented', 'established', 'completed', 'introduced', 'continued', 'launched', 'updated') than to future goals (e.g. 'we expect', 'will continue', 'bode well for the future', 'will provide').

\section{Photographs in 2005 Annual Report}

The photographs in Loblaw's 2005 CAR have a different style than the other years examined. The front cover presents a collage of 36 thumbnail-sized pictures, spread across the page (see the CAR cover at http:/ / www.loblaw.ca/files/doc_financials/ lc105_ar_en.pdf). Though some photographs are blurry, photos of people, products, banners, facilities and services can be identified. The front-cover motto is indistinct: 'We are ...' The next two pages of the CAR (see the inside cover and page 1 of the 
CAR at http://www.loblaw.ca/files/doc_financials/lcl05_ar_en.pdf) present 54 thumbnail photographs organised in six themed $3 \times 3$ grids. All 36 front-cover pictures are incorporated in the grids. Each grid of nine photos includes at least two new pictures. Each grid is labelled: store formats, customer focus, strategic business initiatives, product innovation, national systems and supply chain and 'many strengths, one vision', referring to employee photos. Loblaw's 2005 motto continues between the four grids on page 1 of the CAR: 'We are ... aligning for success'.

One photograph in the 2005 CAR accompanies the LTS. The LTS is signed by both the chairman of the board and the president, and their joint responsibility for the LTS is suggested by their photograph (see page 4 of the CAR at http:/ / www. loblaw.ca/files/doc_financials/lc105_ar_en.pdf). This photograph differs from the photos that accompany the 2002-2004 LTS. The earlier chairman photos (20022004) are similar to each other in style, with the chairman and president wearing the same clothes in each of the three years' photos. In 2002 they are inside a store, in 2003 they are seated, meeting over coffee, and in 2004 they are standing in front of double wall-mounted ovens in a kitchen. The composition of the 2005 CAR photograph is analysed according to principles of portraiture (Davison, 2010). Regarding what Davison termed physical codes, both men are white, middle-aged and smiling slightly. In terms of dress, both men are wearing grey suits and colourful ties. The chairman is wearing a traditional watch and his Order of Canada pin (the highest civilian honour awarded by the Canadian government). From an interpersonal perspective, the photograph shows the president standing beside and slightly behind the chairman. In terms of spatial codes, Davison (2010) identifies the importance of physical space. The photograph of the chairman and president is taken inside the atrium of Loblaw's (then) newly opened head-office building. The men are standing in front of a clear half-wall. Behind and above them are three additional floors of the building, with glass-walled offices. An additional attribute of the setting is a multi-storey architectural feature - a wood-clad column. This feature lists key words in a variety of scripts, sizes and orientations: Leadership, Innovation, Opportunity, Integrity, Discovery, Momentum, Judgement, Creativity, Community, Caring and Courage.

\section{CAR}

\section{Financial Performance}

Loblaw exhibited growth in sales, fixed assets and liabilities in 2006 (see Table 1). However, Loblaw struggled operationally, as reflected in its first net loss in almost two decades, a reduction in total assets, declining profit margin, return-on-assets, cash from operations, return-on-equity and increased levels of debt. This poor performance represents an 'accountability predicament' (Aerts, 2005) for Loblaw. Loblaw's \$219 million loss arose from a non-cash $\$ 800$ million write-down for goodwill impairment.

\section{Letter to Shareholders in 2006 Annual Report}

In 2006, the LTS was written by Galen G. Weston Jr. As the new chair, he focused on products, strengths, implementation of changes, growth, operational improvement and strategic themes. The LTS comments directly on 2006's poor financial 
performance: 'This was the Company's first annual loss in nineteen years' (Loblaw, 2006 CAR, p. 5). This statement, however, identifies the year's performance as an aberration. Responsibility for the loss is attributed to both external and internal causes and helps to manage the reader's impression of the declining financial performance:

\begin{abstract}
Many of the difficulties we faced were the culmination of two important factors. First, there have been significant changes in how food retailers compete and how consumers shop in Canada. The second is Loblaw's own structure, with its history of mergers and acquisitions. The organization is more complex and less responsive than it should have been. These two trends collided in 2006. Loblaw lacked the structural agility and vigour to address its changing environment (Loblaw, 2006 CAR, p. 5).
\end{abstract}

The attribution of poor performance to changes in the industry is consistent with the findings of Clatworthy and Jones (2003) and Aerts (2005). The LTS indicates that internal structural issues are also to blame. However, Galen G. Weston Jr implies the internal issues are ones he inherited and they are thus indirectly attributed to the prior CEO (Clatworthy and Jones, 2003; Godfrey et al., 2003). In contrast with 2005 's focus on past activities, the 2006 LTS has approximately 1.5 statements about the future for every statement about the past. References to the future include 'move forward', a 'first step on our journey', 'will expand', 'our aspirations', 'will introduce', while references to the past comment on 'faced hurdles', 'took stock', 'assessed', 'initiated', 'approved', 'endorsed' and 'embraced'.

Following a 100-Day Review, Loblaw came up with a three-fold plan to 'Simplify, Innovate, Grow'. This motto appears on the 2006 CAR cover. According to Galen G. Weston Jr,

\begin{abstract}
Simplify, Innovate, Grow is an ambitious plan. It is a plan that has been carefully considered and is achievable and already well underway. It is a plan that is conceived and deeply committed to by the new team of senior executives that I have the privilege to lead. And it is one endorsed and embraced by our most important asset - our Loblaw colleagues across Canada. Indeed, it is a plan that once complete, will give our employees the tools they need to do what they do best - serve millions of customers in virtually every community in this great country.

At key moments in its history, Loblaw has been faced with difficult challenges. Each time, it rose to those challenges - transforming itself and Canadian retailing by setting standards admired worldwide. It is that same spirit and determination that inspires the women and men of our Company today to Make Loblaw the Best Again (Loblaw, 2006 CAR, p. 11, emphasis in the original).
\end{abstract}

\title{
Photographs in 2006 Annual Report
}

Photographs in Loblaw's 2006 CAR create an impression of product innovation and breadth. Photographs of Loblaw's pharmacies, banking operations, distribution activities, checkout area, housewares, clothing, bakery, control-label products and fresh produce are included. These photographs stress the range of products and services offered and hint at one-stop shopping. The challenges posed by a wide range of products are implicit in the 2006 CAR motto: 'Simplify, Innovate, Grow'. 
The main photograph on the cover of the CAR is a close-up of an arrangement of apples, accompanied by six smaller photos: four of control-label products, one of a customer and one of an employee.

Galen G. Weston Jr was appointed executive chairman in 2006. His first CAR photograph as chairman was included in an insert accompanying the 2006 Financial Report. ${ }^{8}$ The photograph is a small head-and-shoulders snapshot with his new president and chief merchandising officer. Both men face the camera directly and smile broadly. The president is older than the chairman. Both wear suits and ties. Interpersonally, the photograph depicts the two men standing shoulder to shoulder. They are shown standing in front of a display of produce in a store. While the background is slightly blurry, oranges and various types and colours of apples dominate the display of produce.

\section{CAR}

\section{Financial Performance}

Loblaw's 2007 financial performance was mixed. While sales were up, fixed assets and the number of stores were down (see Table 1). Cash from operations improved, as did the debt/equity ratio (marginally), but liabilities overall were up. Net income increased from a net loss of \$219 million in 2006 to net income of \$330 million. However, had Loblaw not reported the $\$ 800$ million write-down of goodwill in 2006 , the 2006 net income would have been $\$ 581$ million. Had this been the case, then 2007's $\$ 330$ million net income would reflect a continuing deterioration in earnings. To the extent that the timing of the write-down of goodwill was influenced by management discretion, or by the change in leadership (discussed further below), the goodwill write-down may be considered a form of impression management (Aerts, 2005; Clatworthy and Jones, 2003; Godfrey et al., 2003).

\section{Letter to Shareholders in 2007 Annual Report}

The format of the report to shareholders was different in 2007: there is no picture of the author of the report; the report begins with a table highlighting 2007 versus 2006 operating results; and bulleted observations highlight improvements and challenges in 2007 relative to 2006. In the few sentences following this table, the focus is on continued implementation of (transformational) changes, completion of changes to organisational structure and the impact of the transformation on finances (each over 10 per cent of themes: see Table 2), as reflected in the following quote:

2007 was a year of transformational change, amid intense competition and consequent pressured earnings. Despite these challenges in a difficult year, we have made significant progress towards Making Loblaw the Best Again. We completed the first year of our three- to five-year turnaround and made good progress. Our single-most important accomplishment was the completion of our organizational restructuring. As would be expected, there were challenges with a change of this magnitude but Loblaw now, for the first time ever, can fully leverage its national scale (Loblaw, 2007 CAR, p. ii).

Galen G. Weston Jr attributed the challenges Loblaw faced in 2007 to external causes: intense competition and pressured earnings, as well as price competition and an 
'over-spaced' market. This is consistent with Aerts (2005) and Clatworthy and Jones (2003). However, he sees the solution as within managerial control. Attributing progress to managerial action is consistent with self-presentational impression management (Aerts, 2005; Clatworthy and Jones, 2003). In terms of focus, the 2007 LTS has an equal focus on past performance (e.g. 'completed', 'experienced', 'maintained', 'reduced') and future plans (e.g. 'we will use', 'we expect', 'we intend', 'look forward'), suggesting a more balanced LTS.

\section{Photographs in 2007 Annual Report}

Only one photograph appears in the 2007 CAR. The black-and-white photograph on the CAR's front cover occupies the right-hand side of the cover and depicts controllabel products (for example, paper towels, laundry detergent, frozen meat patties, organic baby food, baked goods and frozen dessert) and fresh produce (a head of broccoli, a single strawberry, a banana, an apple, two tomatoes, a bunch of leaf lettuce and a fresh baguette) bursting out of an environmentally friendly, reusable Loblaw grocery bag (see http://www.loblaw.ca/files/doc_financials/lcl07_ar_ en.pdf). Accompanying the photograph is the CAR's motto: 'Making Loblaw the Best Again'. The motto and photograph suggest Loblaw will recapture its 'best' position through innovative control-label products focused on health-conscious, environmentally aware consumers. The 2007 CAR includes no photo of Loblaw's executive chairman.

\section{DISCUSSION}

\section{Impression Management in Loblaw's LTS}

Loblaw's operating results began to deteriorate in 2005, which was attributed to a mix of internal and external factors - Loblaw taking on too much and having difficulty implementing the transformation necessitated by the 'fast-changing retail landscape'. In addition, the 2005 CAR was fairly lengthy, as might be expected to explain the year's comparatively poor results. Perhaps reflecting an uncertain future, Loblaw's 2005 LTS included approximately twice the references to past accomplishments, rather than future plans. This focus on the past may also be reflective of $W$. Galen Weston's as yet unannounced plans to resign as chairman.

With its first loss in almost two decades, 2006 represents an accountability predicament for Loblaw. Although the year's financial performance was poor, the LTS managed the impression of this loss by focusing on Loblaw's prior successes in overcoming challenging times. The promise of the final line of the 2006 LTS to 'Make Loblaw the Best Again' is rhetorically powerful: it acknowledges Loblaw's poor performance, signals responsiveness and reminds the reader of Loblaw's past successes, consistent with managing the impression of 2006's poor financial performance as an aberration. The emphasis in the LTS on attributing poor performance to external and historical factors, the focus on future plans, the lengthy LTS (needed to explain poor performance and to lay out plans for the future) and the collaborative style of the new leader are all consistent with impression management. In addition, the focus in the LTS on future, forward-looking plans is consistent with 
Clatworthy and Jones's (2006) finding that poorly performing firms focus more on the future in their narrative disclosures.

The 2007 CAR seems to signal austerity. While sales, net income and earnings per share all improved, several non-GAAP financial indicators worsened. A few short paragraphs are included in the LTS. Cost-consciousness is a focus of the LTS and it is also signalled by the inclusion of only one photograph in the CAR. These provide the impression that Loblaw is focused on maximising profitability as it strives to be the best again. In 2007, challenges are attributed externally to intense competition and there is an equal focus on past performance and future plans.

Prior impression management research has suggested negative performance is frequently attributed to external, uncontrollable causes while favourable outcomes are attributed to managerial action (Aerts, 2005; Bettman and Weitz, 1983; Clarke, 1997; Clatworthy and Jones, 2003; Thomas, 1997). We find evidence of such self-presentational attributions in Loblaw's LTS, but there is acknowledgement of corporate responsibility for poor results as well, particularly in 2005 and 2006. In 2005, as difficulties implementing the transformation emerge, W. Galen Weston Sr acknowledges the company may have taken on too much, too quickly. The large net loss in 2006 is attributed, not to the write-off of goodwill, but to changing competitive conditions, customer preferences and a lack of agility by the company. Thus Galen G. Weston attributes some of Loblaw's difficulties to structures and processes put in place by his father. In 2007, performance improves only marginally. This is attributed to ongoing intense competition. In spite of this external attribution, the strategies proposed to address competitive pressures are internal ones, reflecting a sense of agency. Consistent with prior research, Loblaw's 2005-2007 LTS frequently attribute poor performance to external factors. However, this is balanced with an acknowledgement that legacy internal structures and processes share some blame. Given that the Weston family, directly or indirectly, controls a majority of the shares of Loblaw, it is relatively safe for the executive chairman to accept some responsibility for poor performance, as he is unlikely to be disciplined by these key shareholders. A second aspect of attributions in the LTS relates to the focus on past results versus future plans. Clatworthy and Jones (2006) noted that companies tend to focus on the future when performance is poor. For Loblaw, the 2005 LTS focused predominantly on past results, but said comparatively little about the future. This seems consistent with W. Galen Weston Sr establishing his legacy in his final full year as chairman. In 2006, Galen G. Weston Jr focused more on future plans, consistent with Clatworthy and Jones (2006). In 2007, comments on the past and future were equal in number. In terms of the length of the LTS, the 2006 LTS was the longest and 2007 was the shortest. This is consistent with Aerts's (2005) observation that negative results need to be explained. Thus, consistent with research question 1 , Loblaw's LTS do provide evidence of impression management, including a pattern of self-presentational attributions.

\section{Impression Management in Loblaw's CAR Photographs}

In the photograph of W. Galen Weston $\mathrm{Sr}$ and his president that accompanied the 2005 LTS, the physical and clothing codes suggest an experienced leadership team focused on running the company from head office. The positioning of the president 
slightly behind the chairman seems to reflect the power differential between them. The clear half-wall behind them suggests transparency. The position of the banner just behind the right shoulder of the chairman, W. Galen Weston, seems to indicate that integrity, judgement, creativity, community, caring and courage are his core values. This is consistent with David's (2001) observation that photographs and LTS in CARs convey corporate values. This is the last photograph of W. Galen Weston in a Loblaw annual report; six months later he resigned as Loblaw's chairman in favour of his son. In hindsight, the photograph takes on greater significance as it reflects his legacy - experienced leadership, values-based management and a commitment to transparency.

The 2005 CAR cover photo is different from all other cover photographs in the period 2002-2010. Every other year's CAR cover has a focal photograph. In fact, in only two years is there more than one photo, so 36 small photos is highly unusual. More typical Loblaw CAR cover photographs are of a store front, fresh produce (particularly apples), or a mix of customers, employees and control-label products. In 2005, Loblaw is working to transform and align its operations, as suggested in the six photographic grids depicting store formats, employees, customers, innovation, strategic initiatives and technology systems and the CAR motto: 'We are ... aligning for success'. Overall, the message conveyed is that Loblaw is imposing order on the various business activities - however, the use of the present tense ('we are aligning') suggests an ongoing process whose results are not yet realised. This cover photo conveys the company's awareness of the challenges it is facing and visually depicts key components of the business being disciplined into order, leaving an impression with the reader that the company is actively responding to external pressures.

The 2006 photograph of Galen G. Weston Jr and his new president suggests the two men are equal: they stand shoulder to shoulder in line with each other. However, the apparent equality of the new leadership team obscures the fact the new chairman is the son of the family with the controlling interest in the corporation. This photograph suggests Galen G. Weston's leadership style is more team-oriented than that of his father. A collaborative approach to leadership is also suggested in statements by Galen G. Weston in which he refers to employees as 'colleagues' and indicates he is privileged to lead his management team. In terms of spatial codes in the photo of Loblaw's new leadership team, positioning them in front of a display of produce suggests these men are 'in the store' and focused on the quality and freshness of produce. This photo helps manage readers' impressions of the new leader by suggesting he is not alone, but has an experienced team assisting him in his new duties, helping to address threats to the legitimacy of his leadership due to his youth and relative inexperience. The 2006 cover photograph reflects the CARs motto: 'Simplify, Innovate, Grow'. The main photo of rows of apples suggests a simpler time; photographs of control-label products suggest innovation, and the photos of a customer and an employee suggest two key areas for growth.

The absence of a photo of the executive chairman in the 2007 CAR is unusual. The 2002-2005 CARs included photos of the chairman and president. The 2006 CAR had a photo of Galen G. Weston Jr and his new president. The 2008-2011 LTS were all accompanied by photos of Galen G. Weston, either alone or with indistinct others, looking away from the camera at someone unseen. In terms of impression 
management, this absence allows readers to propose their own interpretation of the lack of a photo of the executive leader. Possible interpretations could be: cost control is the key concern in 2007; the executive chairman is preoccupied with operational issues and not available for a photo; or it is not clear who is in control and accountable for Loblaw's results. The single black-and-white photograph on the cover of the 2007 CAR suggests both cost control and a focus on produce, control-label products and the environment.

Amernic et al. (2007) and Chatterjee and Hambrick (2007) comment on corporate leadership styles as revealed in CARs. We see clear differences in leadership style reflected in Loblaw's CAR photos. Initially, Loblaw is led by a mature and experienced chairman. In 2006, a changing of the guard takes place. Galen G. Weston, at the age of 33, is appointed executive chairman. We observe Galen G. Weston's development as a leader through his first CARs. In 2006, he is depicted sharing power with his newly appointed president. In 2007, the absence of a photograph of the chairman could be interpreted to suggest a lack of leadership or a leadership team preoccupied with operational issues. While, in 2005, W. Galen Weston Sr was depicted at the height of his power, Galen G. Weston's photographs reflect his evolving leadership style as he gained experience and confidence.

David (2001) and Helms Mills (2005) identify the importance of CAR disclosures in communicating corporate values. Values are reflected in Loblaw's CARs. In the 2005 CAR, W. Galen Weston Sr stands before a tangible statement of values and establishes his legacy: leadership, innovation, opportunity, integrity, judgement, creativity, community, caring and courage are among the values explicitly noted. Galen G. Weston's CARs also convey values, though less explicitly. In 2006, the values communicated in the LTS are innovation, growth and simplification. In 2007, the CAR cover photograph includes new products signalling innovation and concern for the environment, while fresh produce symbolises growth, health and simplicity. These photographs serve to manage the impression readers have of $\mathrm{W}$. Galen Weston's legacy and Galen G. Weston's emerging values, priorities and leadership styles (Davison, 2007, 2010; Helms Mills, 2005).

The photos of Loblaw's executive leaders, as well as the cover photographs for each CAR that signal, respectively, alignment, clarity of focus and austerity, and that reflect each CAR's motto, allow us to answer research question 2 affirmatively, that photos in Loblaw's CARs do show evidence of impression management.

\section{Impression Management and Organisational Legitimacy}

Taken together, Loblaw's LTS and CAR photographs provide evidence of impression management. Research question 3 asks whether these impression management activities can be understood as efforts to restore organisational legitimacy. Threats to organisational legitimacy include changes in CEOs, controversial times or decisions, poor financial results, unfavourable analyst reports, negative share-price movements, and major structural reorganisations (Arndt and Bigelow, 2000; Beelitz and Merkl-Davies, 2012; Godfrey et al., 2003; Merkl-Davies and Brennan, 2011). In 2006, the decision to appoint Galen G. Weston as executive chairman was considered controversial. It surprised stakeholders, resulted in unfavourable analyst reports, the first net loss in nineteen years, a drop in share price and a major 
structural reorganisation. As such, Galen G. Weston's appointment posed a threat to Loblaw's organisational legitimacy - an accountability crisis (Aerts, 2005) - that needed to be managed to rationalise the appointment of a relatively inexperienced family member to a key leadership position.

The use of impression management to restore organisational legitimacy is particularly evident in Galen G. Weston's focus on the future, his attributing poor performance indirectly to his father and his depiction as a member of the new leadership team. There is also evidence that the 2005 CAR uses impression management to establish W. Galen Weston's legacy. In addition to the evidence of impression management in the LTS and CAR photographs described previously, Loblaw's financial performance during the period under examination can also be interpreted as a form of impression management. Poor financial performance in 2006 was attributed to competitive challenges and Loblaw's own legacy structure. Nowhere in the LTS is the timing and magnitude of the write-down of goodwill addressed as a factor in the poor results. However, the poor financial performance is consistent with a 'big bath' where earnings are significantly underreported in the short run, to report higher earnings in the future (Kirschenheiter and Melumad, 2002).

A big bath is considered a means of impression management (Godfrey et al., 2003; Pourciau, 1993) and is particularly common after a change in leadership. Loblaw's 2006 results are consistent with income-reducing behaviour in the year of transition. While the write-down of goodwill is governed by accounting standards, it is an area subject to some management discretion. For example, when discussed in Loblaw's management discussion and analysis (MD\&A), management notes that, based on the related accounting standard, 'any potential goodwill impairment is identified by comparing the fair value of a reporting unit to its carrying value'. The MD\&A goes on to note that the 'process of determining these fair values requires management to make estimates and assumptions ... (regarding) projected future sales, earnings and capital investment'. In terms of the ability of company leadership to influence the amount of impairment recorded, it is noted in the MD\&A that 'projected future sales, earnings and capital investment (used to assess potential goodwill impairment) are consistent with strategic plans presented to the Company's Board of Directors.'. Regarding the timing of the write-down, it is interesting to note that Galen G. Weston Jr was appointed executive chairman in September 2006 (the end of the Company's third quarter), while the goodwill write-off occurred in the fourth quarter of 2006. To the extent that Galen G. Weston articulated a new strategic plan, he would have had some discretion in determining whether goodwill should be considered impaired. The goodwill write-down in 2006, and the subsequent return to profitability in 2007, helped to justify Galen G. Weston's appointment as executive chairman. Together with evidence of impression management in the LTS and CAR photographs, improved financial results in 2007 helped to restore Loblaw's organisational legitimacy.

W. Galen Weston Sr chose to step back from Loblaw's chairmanship when an operational transformation was underway. By resigning at the beginning of a challenging time for Loblaw, W. Galen Weston offered his son an opportunity to take charge of the transformation, perhaps reminiscent of his own appointment to lead Loblaw in 1972 when it was struggling and he was in his early thirties. Galen G. 
Weston Jr used impression management in his first CARs to help demonstrate his competence (Aerts, 2005) and to establish the legitimacy of his leadership (Godfrey et al., 2003) through a return to profitability, providing evidence in support of research question 3 .

\section{CONCLUSION}

Across the years before, during and after a change in executive leadership, there is evidence of impression management in Loblaw's CARs. Loblaw's 2005-2007 CARs provide evidence of impression management in each of the financial results, LTS and photographs. The 2006 net loss, arguably a big bath, means the company's 2007 results appear as an improvement and it seems that Galen G. Weston Jr has improved Loblaw's profitability in his first full year as executive chairman. The LTS attribute agency to Loblaw's responses to internal and external challenges. CAR photographs reflect leadership styles and values. These rhetorical elements seem intended to persuade the reader that company leaders have a plan, are in control and have addressed threats to organisational legitimacy arising from 2006's accountability predicaments.

Incremental information - not included in the financial statements - is provided in LTS and CAR photographs. Reporting in CARs is managed, particularly as it relates to voluntary disclosures (Aerts, 2005; Amir and Ziv, 1997; Clatworthy and Jones, 2003; Darrough and Stoughten, 1990; Davison, 2014; Merkl-Davies and Brennan, 2011). Consistent with prior research, we find new information in the LTS and CAR photographs, beyond the information in the financial statements (Abrahamson and Amir, 1996; Davison, 2014). The focus in 2005 on past accomplishments, compared to the focus in 2006 on future plans, is an additional example of impression management in Loblaw's voluntary CAR disclosures. Voluntary disclosures also convey values (David, 2001; Helms Mills, 2005; Singh and Point, 2006), for example in Loblaw's picture that explicitly refers to corporate values in the 2005 CAR. In other years, values tend to be implicit and require decoding (McGoun et al., 2007; Scott, 1994). The recurring content of Loblaw's non-executive CAR photographs also suggests that innovation, control-label products and fresh produce are valued.

Our analysis of voluntary disclosures over sequential CARs addresses calls made by Beelitz and Merkl-Davies (2012) and Garcia Osma and Guillamon-Saorin (2011) for research into disclosure trends. However, this research is subject to a number of limitations. For example, we did not attempt to create an overall measure of disclosure that would combine text, visuals and financial results. In addition, the use of a case-study approach to evaluate CAR disclosures limits the generalisability of our findings.

We see opportunities for future research on voluntary disclosures with other companies. CARs are one aspect of corporate communications. It would be informative to examine the consistency of corporate messaging not just within the CAR, but in other corporate communications media as well (e.g. press releases, financialanalyst calls, advertisements) (Davison, 2014). Employees are mentioned on several occasions in the LTS and are included in a number of CAR photographs. Exploring 
the content of disclosures referencing employees, relative to the corporate labourrelations context at various companies, would be of interest. For example, does the tone and message in disclosures change during the years when labour issues, such as negotiations or strikes, are taking place (Liberty and Zimmerman, 1986; Waterhouse, Gibbins and Richardson, 1993)? These issues, and others, could be explored in greater depth if access could be gained to discussions taking place at the corporate level as the CAR is being constructed. A detailed case study of the process underlying the choice of text, themes and photographs would be particularly informative.

We respond to calls for more integrative research into CAR disclosures (Beattie et al., 2008), examining simultaneously: financial performance, LTS and photographs in Loblaw's CAR. We explore disclosures across three years, two leaders and in periods of profit and loss for evidence of impression management. We analyse how impression management influences the manner in which leadership, values and attributions are communicated in the LTS and annual report photographs in response to accountability predicaments and to restore organisational legitimacy. We find that voluntary disclosures both support and supplement mandatory disclosures. If voluntary disclosures (LTS and CAR photographs) are read carefully and critically, there is incremental information in them that can inform users' decision-making on whether to support a company as it strives to regain organisational legitimacy following an accountability predicament.

\section{ACKNOWLEDGEMENTS}

We thank the Certified General Accountants of Ontario - Accounting Research Centre at the Telfer School of Management, University of Ottawa, for financial support that facilitated completion of this project. We thank participants at the 2012 IAFA Conference, Galway, Ireland, for their comments. We also acknowledge the excellent research assistance provided by Pui Yi Kong.

\section{ENDNOTES}

1 We thank an anonymous reviewer for providing a clear description of impression management that served as the basis for the definition included here.

2 Loblaw's share price dropped from $\$ 72$ per share at the end of fiscal 2004 to $\$ 34$ per share at the end of fiscal 2006 (Loblaw, 2004, 2006).

3 The Loblaw CARs for 2004 to 2008 were obtained to assess the financial results of the company, but the CAR analysis is based on the transition year of 2006 and the year immediately before and after the transition (2005 to 2007), as the focus of the paper is on impression management relating to the leadership transition period.

4 The research assistant was trained by one of the authors. Training included providing examples of themes within sentences and reviewing the completed coding in detail for reasonableness and accuracy.

5 The relationships between the variables measured (e.g. internal vs external attributions and past vs future references) and the links to impression management were assessed individually by the authors and subsequently discussed to ensure the consistency and appropriateness of interpretation.

6 The post-transition-year trends identified continued through 2010 (for example, the profit margin, return-onassets, return-on-equity and share price were all higher in 2010, as compared to 2008). However, none of these had returned to the pre-2006 (that is, pre-transition) levels. 
Bujaki and McConomy

7 Overall, nineteen distinct themes were identified in the LTS. These are (in descending order of mean percentage inclusion rates): implementation of plans, financial performance, organisational structure, growth, marketing, operational improvement, products, strategy, weaknesses, strengths, customers, employees, challenges, competition, sustainability, leadership, store environment, opportunities and threats.

8 The insert has not been archived on Loblaw's corporate website. However, the insert can be obtained at www. sedar.com by searching for Loblaw's 2006 Annual Report. The photograph of the new executive chairman and his new president appears on page 5 of the CAR.

\section{REFERENCES}

Abrahamson, E. and Amir, E. (1996). The Information Content of the President's Letter to Shareholders, Journal of Business Finance \& Accounting, Vol. 23, No. 8, pp. 1157-1182.

Abrahamson, E. and Park, C. (1994). Concealment of Negative Organizational Outcomes: An Agency Theory Perspective, Academy of Management Journal, Vol. 37, No. 5, pp. 1302-1334.

Aerts, W. (2005). Picking up the Pieces: Impression Management in the Retrospective Attributional Framing of Accounting Outcomes, Accounting, Organizations and Society, Vol. 30, pp. 493-517.

Amernic, J., Craig, R. and Tourish, D. (2007). The Transformational Leader as Pedagogue, Physician, Architect, Commander, and Saint: Five Root Metaphors in Jack Welch's Letters to Stockholders of General Electric, Human Relations, Vol. 60, No. 12, pp. 1839-1872.

Amir, E. and Ziv, A. (1997). Economic Consequences of Alternative Adoption Rules for New Accounting Standards, Contemporary Accounting Research, Vol. 14, No. 3, pp. 543-568.

Arndt, M. and Bigelow, B. (2000). Presenting Structural Innovation in an Institutional Environment: Hospitals' Use of Impression Management, Administrative Science Quarterly, Vol. 45, No. 3, pp. 494-522.

Barthes, R. (1982). Rhetoric of the Image in Image, Music, Text, S. Heath, translator, London: Fontana Press, pp. 32-51.

Beattie, V., Dhanani, A. and Jones, M.J. (2008). Investigating Presentational Change in UK Annual Reports: A Longitudinal Perspective, Journal of Business Communication, Vol. 45, No. 2, pp. 181-222.

Beelitz, A. and D.M. Merkl-Davies (2012). Using Discourse to Restore Organizational Legitimacy: 'CEO-speak' after an Incident in a German Nuclear Power Plant, Journal of Business Ethics, Vol. 108, No. 1, pp. 101-120.

Benschop, Y. and Meihuizen, H.E. (2002). Keeping up Gendered Appearances: Representations of Gender in Annual Reports, Accounting, Organizations and Society, Vol. 27, No. 7, pp. 611-636.

Bettman, J. and Weitz, B. (1983). Attributions in the Board Room: Causal Reasoning in Corporate Annual Reports, Administrative Science Quarterly, Vol. 28, pp. 165-183.

Bujaki, M. and McConomy, B. (2012). Metaphor in Nortel's Letters to Shareholders 19972006, Accounting, Auditing \& Accountability Journal, Vol. 25, No. 7, pp. 1113-1139.

CBC (2013). The Weston Family Empire Expands Again, CBC News, 16 July, available from http://www.cbc.ca/news/canada/the-weston-family-empire-expands-again-1.1313575, accessed 16 May 2014.

Chatterjee, A. and Hambrick, D. (2007). It's All about Me: Narcissistic Chief Executive Officers and their Effects on Company Strategy and Performance, Administrative Science Quarterly, Vol. 52, pp. 351-386.

Clarke, G. (1997). Messages from CEOs: A Content Analysis Approach, Corporate Communications, Vol. 2, No. 1, pp. 31-39. 
Clatworthy, M. and Jones, M. (2003). Financial Reporting of Good News and Bad News: Evidence from Accounting Narratives Accounting and Business Research, Accounting and Business Research, Vol. 33, No. 3, pp. 171-185.

Clatworthy, M. and Jones, M. (2006). Differential Patterns of Textual Characteristics and Company Performance in the Chairman's Statement, Accounting, Auditing \& Accountability Journal, Vol. 19, No. 4, pp. 493-511.

Darrough, M. and Stoughton, N. (1990). Financial Disclosure Policy in an Entry Game, Journal of Accounting and Economics, Vol. 12, Nos. 1-3, pp. 219-243.

Datamonitor (2006). Food retail in Canada industry profile, May.

David. C. (2001). Mythmaking in Annual Reports, Journal of Business and Technical Communication, Vol. 15, No. 2, pp. 195-222.

Davison, J. (2007). Photographs and Accountability: Cracking the Codes of an NGO, Accounting, Auditing \& Accountability Journal, Vol. 20, No. 1, pp. 133-158.

Davison, J. (2010). [In]visible [in]tangibles: Visual Portraits of the Business Elite, Accounting, Organizations and Society, Vol. 35, pp. 165-183.

Davison, J. (2014). Visual Rhetoric and the Case of Intellectual Capital, Accounting, Organizations and Society, Vol. 39, No. 1, pp. 20-37.

Davison, J. and Warren, S. (2009). Imag[in]ing Accounting and Accountability. Accounting, Auditing \& Accountability Journal, Vol. 22, No. 6, pp. 845-857.

Devinney, T. and Kabanoff, B. (1999). Doing What They Say or Saying What They Do? Australian Organisations' Signals of Performance and Attitudes, Australian Journal of Management, Vol. 24, No. 1, pp. 59-75.

Garcia Osma, B. and Guillamon-Saorin, E. (2011). Corporate Governance and Impression Management in Annual Results Press Releases, Accounting, Organizations and Society, Vol. 36, No. 4-5, pp. 187-208.

Godfrey, J., Mather, P. and Ramsay, A. (2003). Earnings and Impression Management in Financial Reports: The Case of CEO Changes, Abacus, Vol. 39, No. 1, pp. 95-123.

Graves, O., Flesher, D. and Jordan, R. (1996). Pictures and the Bottom Line: Television and the Epistemology of US Annual Reports, Accounting, Organizations and Society, Vol. 21, No. 1, pp. 57-88.

Helms Mills, J. (2005). Organizational Change and Representations of Women in a North American Utility Company, Gender, Work and Organization, Vol. 12, No. 3, pp. 242-269.

Hyland, K. (1998). Exploring Corporate Rhetoric: Metadiscourse in the CEO's Letter, The Journal of Business Communication, Vol. 35, No. 2, pp. 224-245.

Kirschenheiter, M. and Melumad, N. (2002). Can 'Big Bath' and Earnings Smoothing Co-exist as Equilibrium Financial Reporting Strategies?, Journal of Accounting Research, Vol. 40, No. 3, pp. 761-796.

Kohut, G. and Segars, A. (1992). The President's Letter to Stockholders: An Examination of Corporate Communication Strategy, The Journal of Business Communication, Vol. 29, No. 1, pp. 7-21.

Liberty, S. and Zimmerman, J. (1986). Labor Union Contract Negotiations and Accounting Choices, The Accounting Review, Vol. 61, No. 4, pp. 692-713.

Loblaw (2004). Corporate Annual Report.

Loblaw (2005). Corporate Annual Report.

Loblaw (2006). Corporate Annual Report.

Loblaw (2007). Corporate Annual Report.

Loblaw (2008). Corporate Annual Report.

Maltby, J. and Tsamenyi, M. (2010). Narrative Accounting Disclosure: Its Role in the Gold Mining Industry on the Gold Coast 1900-1949, Critical Perspectives on Accounting, Vol. 21, pp. 390-401. 
McGoun, E., Bettner, M. and Coyne, M. (2007). Pedagogic Metaphors and the Nature of Accounting Signification, Critical Perspectives on Accounting, Vol. 8, pp. 213-230.

McKinstry, S. (1996). Designing the Annual Reports of Burton plc from 1930 to 1994, Accounting, Organizations and Society, Vol. 21, No. 1, pp. 89-111.

Merkl-Davies, D.M. and Brennan, N.M. (2011). A Conceptual Framework of Impression Management: New Insights from Psychology, Sociology, and Critical Perspectives, Accounting and Business Research, Vol. 41, No. 5, pp. 415-437.

National Post. (2006). Guarding the Family Jewel, National Post, 30 September, available at $<$ http:/ / www.canada.com/nationalpost/ financialpost/ story.html?id=3687703b-f2064f7c-aa5f-dfdd199610f6>, accessed 18 June 2014.

New York Times (1983). Attempt to Abduct Rich Businessman in Ireland is Foiled, The New York Times, 8 August, available at <http://www.nytimes.com/1983/08/08/world/ attempt-to-abduct-rich-businessman-in-ireland-is-foiled.html>, accessed 18 June 2014.

Ogden, S. and Clarke, J. (2005). Customer Disclosures, Impression Management and the Construction of Legitimacy: Corporate Reports in the UK Privatised Water Industry, Accounting, Auditing \& Accountability Journal, Vol. 18, No. 3, pp. 313-345.

Olijnyk, Z. (2006). All in the Family: Weston Undergoes a Shakeup, Canadian Business, 22 September, available from <http://www.canadianbusiness.com/business-strategy/allin-the-family-weston-undergoes-a-shakeup/>, accessed 16 May 2014.

Poisson, J. (2012). Toronto's Hilary Weston Dubbed Richest Person in Ireland - for the Fourth Year in a Row, Toronto Star, 30 April 2012, available from http:/ / www.thestar.com/news/ gta/2012/04/30/torontos_hilary_weston_dubbed_richest_person_in_ireland_for_the_ fourth_year_in_a_row.html, accessed 16 May 2014.

Pourciau, S. (1993). Earnings Management and Nonroutine Executive Changes, Journal of Accounting and Economics, Vol. 16, No. 1-3, pp. 317-336.

Prasad, A. and Mir, R. (2002). Digging Deep for Meaning: A Critical Hermeneutic Analysis of CEO Letters to Shareholders in the Oil Industry, The Journal of Business Communication, Vol. 39, No. 1, pp. 92-116.

Scott, L. (1994). Images in Advertising: The Need for a Theory of Visual Rhetoric, Journal of Consumer Research, Vol. 21, No. 2, pp. 252-273.

Singh, V. and Point, S. (2006). (Re)Presentations of Gender and Ethnicity in Diversity Statements on European Company Websites, Journal of Business Ethics, Vol. 68, pp. 363-379.

Suchman, M. (1995). Managing Legitimacy: Strategic and Institutional Approaches, Academy of Management Review, Vol. 20, No. 3, pp. 571-610.

Suddaby, R. and Greenwood, R. (2005). Rhetorical Strategies of Legitimacy, Administrative Science Quarterly, Vol. 50, No. 1, pp. 35-67.

Thomas, J. (1997). Discourse in the Marketplace: The Making of Meaning in Annual Reports, The Journal of Business Communication, Vol. 34, No. 1, pp. 47-66.

Waterhouse, J., Gibbins, M. and Richardson, A. (1993). Strategic Financial Disclosure: Evidence from Labor Negotiations, Contemporary Accounting Research, Vol. 9, pp. 526-550.

Yahoo Finance (2014), Loblaw Companies Limited, Historical Prices, available from <http:/ / finance. $y$ ahoo.com/q/hp? $=$ L.TO\&a $=08 \& b=18 \& c=2006 \& d=08 \& e=30 \& f=2006 \& g=d>$, accessed 18 June 2014. 